\title{
Site selection for EVCSs by GIS-based AHP method
}

\author{
Linzhao $S U N^{I^{*}}$ \\ ${ }^{1}$ Tsinghua-Berkeley Shenzhen Institute, Tsinghua University, 518055 Shenzhen, P.R.China
}

\begin{abstract}
As an alternative to fossil-fuelled vehicles, electric vehicles (EVs) are eco-friendly which can reduce carbon emissions and improve energy efficiency. However, there are still some barriers to the development of EVs. One of the main problems is lacking scientific planning of charging stations considering social, technological and environmental factors. To solve the problem, our paper proposes a Geographic Information System (GIS)-based AHP method to find optimal locations of electric vehicle charging stations (EVCSs) in Nanshan District, Shenzhen City. From the experimental result, the middle and southeast are more suitable to locate charging stations than other areas.18 alternative stations are selected considering the reality and existed charging stations.
\end{abstract}

\section{Introduction}

As an alternative to fossil fuels, electric vehicles play an important role in reducing carbon emissions and improving energy efficiency. Due to EVs' benefits and government's support, the number of them is increasing at a rapid speed. In 2019, electric cars in the world exceeded 7.2 million. China remains the world's largest electric car market: around $47 \%$ of electric cars on the road in 2019 were in this country ${ }^{[1]}$.

However, charging infrastructure is not coordinated with the development of electric vehicles. On the one hand, in some areas, EVs are growing faster, but the scale of charging infrastructure is insufficient; on the other hand, due to the problem of unreasonable planning, the growth of electric vehicles is generally lower than expected. Charging infrastructure construction needs to consider planning, land use, electricity and other prerequisites, involving multiple management departments and related enterprises. Construction of charging infrastructure in social parking lot involves many scattered stakeholders, which means coordination is difficult ${ }^{[2]}$.

This paper mainly aims to solve the problem mentioned above. There are many factors need to be considered, such as technologies, facilities, environment and land use. The multi-criteria involving important factors are introduced into the research ${ }^{[3]}$. GIS is used for dealing with the layer of different criteria and finding the accurate sites of EVs. Therefore, a GIS-based multicriteria method is proposed in this paper ${ }^{[4]}$.

This paper takes six steps to find optimal locations of EVCSs. Firstly, we set up a 4 criteria AHP with 18 subcriteria and find the data of the sub-criteria from open source. Secondly, we use GIS to map, process and union 18 factors. Thirdly, we organize professors to compare criteria by AHP method and calculate the weights of each criterion. Fourthly, we put weights into GIS and get the final scores of the given area. Fifthly, we select alternative charging stations by final scores. Finally, we use TOPSIS method to rank the alternative charging stations and choose the optimal ones.

\section{Literature Review}

Location planning of EVCSs is a decision-making problem and there are many researchers using decisionmaking method to find optimal sites ${ }^{[5-10]}$.

Location planning of EVCSs is also a multiple-criteria decision-making (MCDM) problem considering complicated criteria, which means that MCDM can solve the problem ${ }^{[11-13]}$. There was no GIS used in the aforementioned studies. Site planning is a geographic problem involving spatial analysis, so GIS can be combined with MCDM to solve the problem. GIS can integrate and process spatial data. And MCDM provides a scientific decision system involving multi-criteria. GISbased MCDM has been used in some papers to solve the planning problem ${ }^{[14-17]}$.

All of the mentioned methods can be applied to select optimal locations of EVCSs, whereas researchers establish an evaluation system with a small quantity of criterion. So in this paper, we set up a location evaluation system with 18 criteria and classify the social criteria specifically with social life and service. GIS-based AHP method is proposed and TOPSIS is used to rank the alternative stations.

\section{Methodology}

\subsection{Geographic Information System}

Geographic Information System (GIS) is a computer system used to capture, store, check and display data related to the location of the earth's surface. GIS can

\footnotetext{
* Corresponding author: sunlinzhao@foxmail.com
} 
display many different types of data on a map. This makes it easier for people to view, analyse, and understand patterns and relationships.

\subsection{Analytic Hierarchy Process}

According to the problem to be solved, the decision maker chooses essential factors and combines them at different levels according to the relativity of the factors to form a multi-level analysis structure model.

The technique derives relative scores for competing elements by assessments from experts. Based on the pairwise comparison of elements, it generates a comparison matrix to determine the relative weight of each element. The final problem comes down to the determination of the relative importance of the lowest level relative to the highest level and ranking the sequence.

This research uses a square matrix to calculate the relative weight. The relative scores are judged by four experts from related areas.

The pairwise comparison scale is used in AHP ${ }^{[18]}$. The table shows the Saaty's 9 relative scores given to the experts and stakeholders.

Calculate the average of the relative scores and get the pairwise matrix expressed in $\mathbf{E q} 1$.

$$
\mathrm{M}=\left[\begin{array}{ccc}
C_{11} & \cdots & C_{1 n} \\
\vdots & \ddots & \vdots \\
C_{n 1} & \cdots & C_{n n}
\end{array}\right]
$$

Use the square root method to produce and normalize the rows of matrix A to obtain the eigenvector $\mathrm{W}$. Calculate the largest Eigenvalues. The eigenvalues are expressed in Eq 2.

$$
\begin{aligned}
A W & =\lambda_{\text {max }} W \\
\lambda_{\text {max }} & =\frac{1}{n} \sum_{i} \frac{(A W)_{i}}{W_{i}}
\end{aligned}
$$

Check the consistency ratio. The experts' scores may be inconsistent, therefore, the consistency ratio is introduced to ensure the relative scores are effective.

$$
\begin{gathered}
\mathrm{CI}=\frac{\lambda_{\max }-n}{n-1} \\
C R=\frac{C I}{R I}
\end{gathered}
$$

Where $\mathrm{CI}$ is the consistency index and RI is the mean consistency index, determined by the matrix dimension.

If the index $\mathrm{CR}<0.1$, the consistency of the matrix is acceptable. When $\mathrm{CR} \geqslant 0.1$, the pairwise comparison judgment should be performed again.

Table 1. RI values with corresponding matrix dimension

\begin{tabular}{|c|c|c|}
\hline 1 & $\begin{array}{l}\text { Equal } \\
\text { importance }\end{array}$ & $\begin{array}{l}i \text { and } j \text { are preferred } \\
\text { equally }\end{array}$ \\
\hline 3 & $\begin{array}{l}\text { Moderate } \\
\text { importance }\end{array}$ & $\begin{array}{l}i \text { is moderately more } \\
\text { important than } j\end{array}$ \\
\hline 5 & $\begin{array}{l}\text { Strong } \\
\text { importance }\end{array}$ & $\begin{array}{l}i \text { is strongly more } \\
\text { important than } j\end{array}$ \\
\hline 7 & $\begin{array}{l}\text { Very strong } \\
\text { importance }\end{array}$ & $\begin{array}{l}i \text { is very strongly } \\
\text { more important than } \\
j\end{array}$ \\
\hline 9 & $\begin{array}{l}\text { Absolute } \\
\text { importance }\end{array}$ & $\begin{array}{l}i \text { is absolutely more } \\
\text { important than } j\end{array}$ \\
\hline $2,4,6,8$ & $\begin{array}{l}\text { Intermediate } \\
\text { values between } \\
\text { the two } \\
\text { adjacent } \\
\text { judgments }\end{array}$ & Intermediate values \\
\hline
\end{tabular}

\begin{tabular}{|l|l|l|l|l|l|l|l|}
\hline $\mathrm{n}$ & 1 & 2 & 3 & 4 & 5 & 6 & 7 \\
\hline $\mathrm{RI}$ & 0.00 & 0.00 & 0.58 & 0.90 & 1.12 & 1.24 & 1.32 \\
\hline 8 & 9 & 10 & 11 & 12 & 13 & 14 & 15 \\
\hline 1.41 & 1.45 & 1.49 & 1.51 & 1.48 & 1.56 & 1.57 & 1.59 \\
\hline
\end{tabular}

Table 2. Comparison Scale

\begin{tabular}{|l|l|l|}
\hline $\begin{array}{l}\text { Intensity } \\
\text { of } \\
\text { importance }\end{array}$ & Definition & Explanation \\
\hline
\end{tabular}

\subsection{TOPSIS}

TOPSIS is a commonly used comprehensive evaluation method within the group, which can make full use of the original data, and accurately reflect the gap among various evaluation systems.

Assuming that there are $\mathrm{m}$ objects to be evaluated, and each object has $\mathrm{n}$ indicators, the original data matrix is constructed as:

$$
\mathbf{M}=\left[\begin{array}{ccc}
x_{11} & \cdots & x_{1 n} \\
\vdots & \ddots & \vdots \\
x_{n 1} & \cdots & x_{n n}
\end{array}\right]
$$

Construct a weighted canonical matrix, and vector normalize the attributes.

$$
\overline{X_{l J}}=\frac{X_{i j}}{\sqrt{\sum_{i=1}^{m} X_{i j}^{2}}}
$$

Normalize the matrix $\mathrm{X}$ and get the normalization matrix $\mathrm{Z}$

$$
\mathrm{Z}=\left[\begin{array}{ccc}
Z_{11} & \cdots & Z_{1 n} \\
\vdots & \ddots & \vdots \\
Z_{n 1} & \cdots & Z_{n n}
\end{array}\right]
$$

Determine the best and worst solutions

The optimal solution $\mathrm{Z}^{+}$consists of the maximum value of each column of elements in $\mathrm{Z}$ :

$$
\begin{aligned}
& Z^{+}=\left(\max \left\{z_{11}, z_{21}, \ldots, z_{n 1}\right\}, \ldots, \max \left\{z_{1 m}, z_{2 m}, \ldots, z_{n m}\right\}\right)= \\
& \left(Z_{1}^{+}, Z_{2}^{+}, \ldots Z_{m}^{+}\right) \\
& Z^{-}=\left(\min \left\{z_{11}, Z_{21}, \ldots, z_{n 1}\right\}, \ldots, \min \left\{z_{1 m}, Z_{2 m}, \ldots, z_{n m}\right\}\right)= \\
& \left(Z_{1}^{-}, Z_{2}^{+}, \ldots Z_{m}^{+}\right)
\end{aligned}
$$

Calculate the distance of each evaluation object to the optimal solution and the worst solution

$$
D_{i}^{+}=\sqrt{\sum_{j=1}^{m} w_{j}\left(Z_{j}^{+}-z_{i j}\right)^{2}}
$$




$$
D_{i}^{-}=\sqrt{\sum_{j=1}^{m} w_{j}\left(Z_{j}^{-}-z_{i j}\right)^{2}}
$$

Where $w_{j}$ is the weight of the $\mathrm{j}$ attribute that is determined by AHP method.

Calculate the closeness of each evaluation object to the optimal solution.

$$
\begin{aligned}
& C_{i}=\frac{D_{i}^{-}}{D_{i}^{-}+D_{i}^{+}} \\
& 0 \leq C_{i} \leq 1
\end{aligned}
$$

The closer $C_{i}$ to 1 , the better of i solution. Rank solutions according to the values of $C_{i}$.

\section{Application of methodology}

\subsection{Study Area}

Nanshan District locates in the central and western part of Shenzhen, Guangdong Province. It had a population of 1,493,600 in 2018 and its GDP reached 501.8 billion yuan, with a per capita GDP of more than 50,000 US dollars in the same year. Its total economic output ranked third in the country's districts and first in Guangdong for six consecutive years. The land area of the jurisdiction is $187.47 \mathrm{~km}^{2}$, and the coastline is $43.7 \mathrm{~km}$.

After the web crawler from Baidu Map, the number of the charging stations in Nanshan District is 321, which is insufficient for electric vehicles. The existing charging stations are mainly located at the constructions and some of them are inconvenient for the drivers. Therefore, according to the scientific planning of charging stations, more reasonable sites of charging stations need to be selected.

\subsection{Data Selection and Collection}

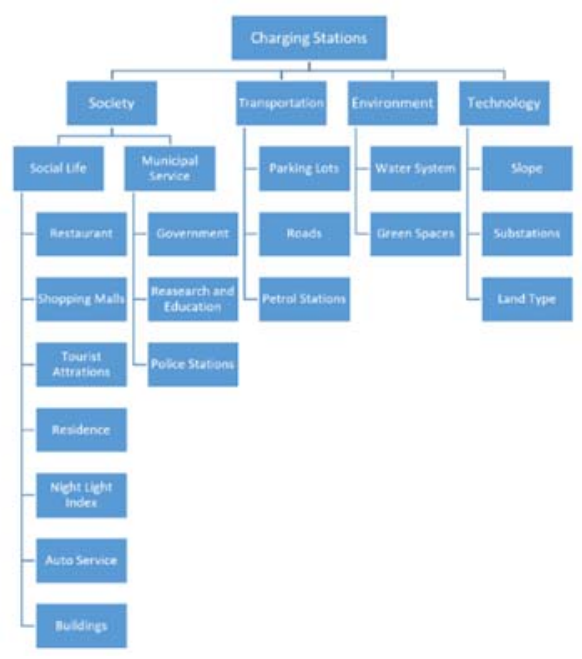

Fig. 1. The evaluation system for locations of EVCSs

By discussing with four experts, the evaluation system can be divided into four main criteria, which are society, transportation, environment, technology. And the evaluation system is listed in Fig. 1.

(1)Society means the possible places for using electric vehicles and represent the distribution of Electric Vehicles. From the social perspective, the criteria should cover people's social life and municipal services which decide people's day and night driving rule and reflect residence's living conditions. The sub-criteria of social life are restaurants, shopping malls, tourist attractions, Night Light Index, Auto Services and buildings. The subcriteria of municipal service are government, research, education and police stations.

(2)Transportation means the accessibility of electric vehicles. The sub-criteria of transportation are parking lots, roads and petrol stations.

(3)The environmental factor should be considered because the construction of charging stations can have a bad effect on the environment such as discharging wastewater when washing vehicles and renewing battery, which may pollute the water and green places.

(4)The technology factor can measure technological difficulty of the constructions considering electrical grid and geographic conditions. The land type is the technology criterion which is multiplied with value 0 or 1 to decide whether the land can be used to construct charging stations according to government planning.

The data is mainly collected from open data of Baidu Map, which is POI point data in Nanshan District.

\subsection{AHP}

The experts compare the criteria according to the comparison scale and form the pairwise matrix by discussing the problem. We use python to calculate the inconsistency ratio of the matrix.

Table 3. Pairwise comparison matrix of main criteria

\begin{tabular}{|l|l|l|l|l|}
\hline & $\begin{array}{l}\text { Soci } \\
\text { ety }\end{array}$ & $\begin{array}{l}\text { Transport } \\
\text { ation }\end{array}$ & $\begin{array}{l}\text { Environ } \\
\text { ment }\end{array}$ & $\begin{array}{l}\text { Technolo } \\
\text { gy }\end{array}$ \\
\hline Society & 1 & 3 & 3 & 2 \\
\hline Transportation & $1 / 3$ & 1 & 1 & 2 \\
\hline Environment & $1 / 3$ & 1 & 1 & 2 \\
\hline Technology & $1 / 2$ & $1 / 2$ & $1 / 2$ & 1 \\
\hline
\end{tabular}

Table 4. Pairwise comparison matrix of sub-criteria

\begin{tabular}{|l|l|l|l|l|l|l|l|}
\hline & $\begin{array}{l}\text { Restau } \\
\text { rant }\end{array}$ & $\begin{array}{l}\text { Shop } \\
\text { ping }\end{array}$ & $\begin{array}{l}\text { Tou } \\
\text { rist }\end{array}$ & $\begin{array}{l}\text { Resi } \\
\text { denc } \\
\mathrm{e}\end{array}$ & $\begin{array}{l}\text { Nigh } \\
\mathrm{t}\end{array}$ & $\begin{array}{l}\text { Au } \\
\text { to }\end{array}$ & $\begin{array}{l}\text { Buildi } \\
\text { ngs }\end{array}$ \\
\hline $\begin{array}{l}\text { Restau } \\
\text { rant }\end{array}$ & 1 & $1 / 7$ & $1 / 5$ & $1 / 3$ & $1 / 8$ & 2 & $1 / 7$ \\
\hline $\begin{array}{l}\text { Shopp } \\
\text { ing }\end{array}$ & 7 & 1 & 3 & 6 & $1 / 4$ & 8 & 1 \\
\hline $\begin{array}{l}\text { Touris } \\
\mathrm{t}\end{array}$ & 5 & $1 / 3$ & 1 & 4 & $1 / 5$ & 6 & $1 / 3$ \\
\hline $\begin{array}{l}\text { Reside } \\
\text { nce }\end{array}$ & 3 & $1 / 6$ & $1 / 5$ & 1 & $1 / 7$ & 4 & $1 / 6$ \\
\hline
\end{tabular}




\begin{tabular}{|l|l|l|l|l|l|l|l|}
\hline Night & 8 & 4 & 5 & 7 & 1 & 9 & 2 \\
\hline Auto & $1 / 2$ & $1 / 8$ & $1 / 6$ & $1 / 4$ & $1 / 9$ & 1 & $1 / 8$ \\
\hline $\begin{array}{l}\text { Buildi } \\
\text { ngs }\end{array}$ & 7 & 1 & 3 & 6 & $1 / 2$ & 8 & 1 \\
\hline
\end{tabular}

Table 5. Pairwise comparison matrix of sub-criteria

\begin{tabular}{|l|l|l|l|}
\hline & Government & $\begin{array}{l}\text { Research and } \\
\text { Education }\end{array}$ & $\begin{array}{l}\text { Police } \\
\text { Stations }\end{array}$ \\
\hline Government & 1 & $1 / 3$ & 2 \\
\hline $\begin{array}{l}\text { Research and } \\
\text { Education }\end{array}$ & 3 & 1 & 4 \\
\hline Police Stations & $1 / 2$ & $1 / 4$ & 1 \\
\hline
\end{tabular}

Table 6. Pairwise comparison matrix of sub-criteria

\begin{tabular}{|l|l|l|l|}
\hline & $\begin{array}{l}\text { Parking } \\
\text { Lots }\end{array}$ & Road & Petrol Stations \\
\hline Parking Lots & 1 & 3 & 2 \\
\hline Road & $1 / 3$ & 1 & $1 / 2$ \\
\hline Petrol Stations & $1 / 2$ & 2 & 1 \\
\hline
\end{tabular}

Table 7. Pairwise comparison matrix of sub-criteria

\begin{tabular}{|l|l|l|}
\hline & Social Life & Municipal Service \\
\hline Social Life & 1 & $7 / 3$ \\
\hline Municipal Service & $3 / 7$ & 1 \\
\hline
\end{tabular}

Table 8. Pairwise comparison matrix of sub-criteria

\begin{tabular}{|l|l|l|}
\hline & Water System & Green Spaces \\
\hline Water System & 1 & 1 \\
\hline Green Spaces & 1 & 1 \\
\hline
\end{tabular}

Table 9. Pairwise comparison matrix of sub-criteria

\begin{tabular}{|l|l|l|}
\hline & Slope & Substations \\
\hline Slope & 1 & 1 \\
\hline Substations & 1 & 1 \\
\hline
\end{tabular}

Table 10. The consistency ratio

\begin{tabular}{|l|l|l|l|l|}
\hline & $\lambda \_\max$ & \multicolumn{1}{|c|}{ CI } & CR & $\mathrm{n}$ \\
\hline Social Life & 7.485 & 0.0808 & 0.0612 & 7 \\
\hline $\begin{array}{l}\text { Municipal } \\
\text { Service }\end{array}$ & 3.018 & 0.009 & 0.0155 & 3 \\
\hline Transportation & 3.009 & 0.0045 & 0.00776 & 3 \\
\hline $\begin{array}{l}\text { Charging } \\
\text { Stations }\end{array}$ & 4.155 & 0.0517 & 0.0574 & 4 \\
\hline
\end{tabular}

The CI indexes shown in Table 10. indicate that the consistency of the matrix is acceptable.

\subsection{GIS}

This paper uses eighteen evaluation criteria to determine optimal locations of charging stations. The data is obtained by shapefiles from Open Sources and added into the same geographic coordinate system. Then the values of each criterion are processed and obtained by ArcGIS software.

We construct multi-ring buffers assigned with integral values. The land value is classified into construction land and non-construction land and assigned with values of 1 and 0 , respectively. We use the calculator tool to calculate the final scores in the final layer. After converting the final layer features to raster $(100 * 100 \mathrm{~m})$, the final layer is reclassified into 15 categories at equal intervals. We extract the highest scores, then set up charging stations according to the exited charging stations and the reality.

\section{Results and Discussion}

\subsection{Results}

According to the final scores shown in Fig. 2, the red colour means the higher scores. The middle and southeast get higher scores than other areas. 18 alternative stations are selected considering the actual situation and existed charging stations and shown in Fig. 3.

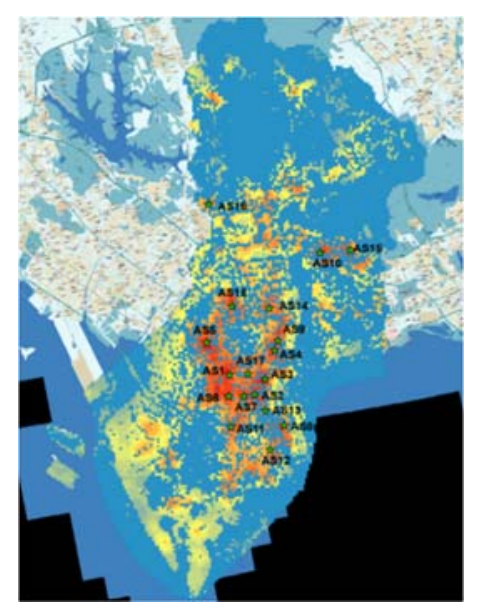

Fig. 2. Suitability map for locations of EVCSs

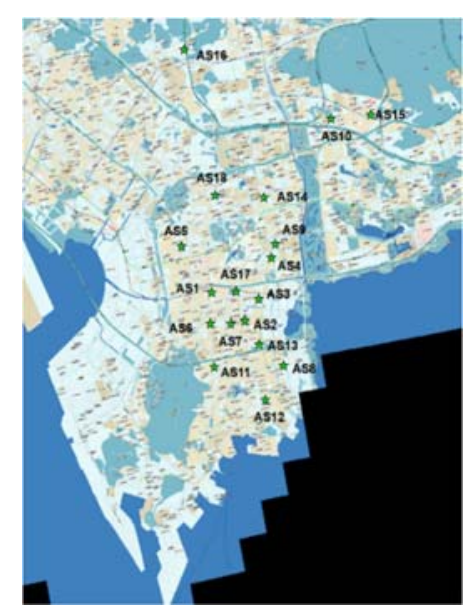


Fig. 3. Alternative stations of EVCSs

We use TOPSIS to rank the alternative stations. The results are shown in Table 11. The top of the ranking is distributed in the middle part.

Table 11. Ranking of alternative stations

\section{Ranking}

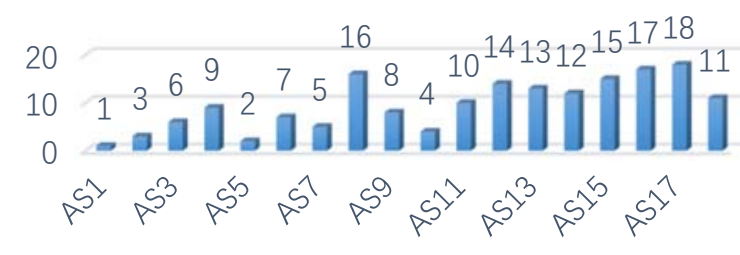

\section{Conclusion}

EVs are growing faster in countries that are under EV adoption policies such as China, but there is still a large gap between demand and supply of charging stations. To avoid unreasonable distribution and increase the efficiency of EVCSs, a scientific decision system should be developed.

In this paper, we leverage a GIS-based AHP solution to determine suitable locations of EVCS, considering four criteria and eighteen sub-criteria. TOPSIS method is used to rank the alternative stations and the result show that AS1 $\backslash$ AS5 $\backslash$ AS2 are the first three alternative stations.

\section{References}

1. "Global EV Outlook 2020-Analysis-IEA," https://www.iea.org/reports/global-ev-outlook-2020.

2. "Guidelines for the Development of Electric Vehicle Charging Infrastructure http://www.gov.cn/zhengce/201510/09/content_5076250.htm

3. A. Liu, Y. Zhao \& X. Meng et al., "A three-phase fuzzy multi-criteria decision model for charging station location of the sharing electric vehicle," International Journal of Production Economics, Vol.225(2020), p.107572.

4. Ö. Kaya, A. Tortum \& K. D. Alemdar et al., "Site selection for EVCS in Istanbul by GIS and multicriteria decision-making," Transportation Research Part D: Transport and Environment, Vol.80(2020), p.102271.

5. T.H. Tran, G. Nagy \& T. B. T.Nguyen et al., "An efficient heuristic algorithm for the alternative-fuel station location problem," European Journal of Operational Research, Vol.269, No.1(2018), pp.159170.

6. F. Guo, J. Yang \& J. Lu, "The battery charging station location problem: Impact of users' range anxiety and distance convenience," Transportation
Research Part E: Logistics and Transportation Review, Vol.114(2018), pp.1-18.

7. C. Bian, H. Li \& F. Wallin et al., "Finding the optimal location for public charging stations - a GISbased MILP approach," Energy Procedia, Vol.158(2019), pp.6582-6588.

8. X. Bai, K. Chin \& Z. Zhou, "A bi-objective model for location planning of electric vehicle charging stations with GPS trajectory data," Computers \& Industrial Engineering, Vol.128(2019), pp.591-604.

9. H. Zhang, L. Tang \& C. Yang et al., "Locating electric vehicle charging stations with service capacity using the improved whale optimization algorithm," Advanced Engineering Informatics, Vol.41(2019), p.100901.

10. Q. Liu, J. Liu \& W. Le et al., "Data-driven intelligent location of public charging stations for electric vehicles," Journal of Cleaner Production, Vol.232(2019), pp.531-541.

11. Z. Tang, C. Guo \& P. Hou et al., "Optimal Siting of Electric Vehicle Charging Stations Based on Voronoi Diagram and FAHP Method," Energy and Power Engineering, Vol.5, No.4(2013), pp.1404-1409.

12. S. Guo \& H. Zhao, "Optimal site selection of electric vehicle charging station by using fuzzy TOPSIS based on sustainability perspective," Applied Energy, Vol.158(2015), pp.390-402.

13. Y. Wu, M. Yang \& H. Zhang et al., "Optimal Site Selection of Electric Vehicle Charging Stations Based on a Cloud Model and the PROMETHEE Method," Energies, Vol.9, No.3(2016), p.157.

14. H. Zhao \& N. Li, "Optimal Siting of Charging Stations for Electric Vehicles Based on Fuzzy Delphi and Hybrid Multi-Criteria Decision Making Approaches from an Extended Sustainability Perspective," Energies, Vol.9, No.4(2016), p.270.

15. M. Erbaş, M. Kabak \& E. Özceylan et al., "Optimal siting of electric vehicle charging stations: A GISbased fuzzy Multi-Criteria Decision Analysis," Energies, Vol.163(2018), pp.1017-1031.

16. J. Zhou, Y. Wu \& C. Wu et al., "A geographical information system based multi-criteria decisionmaking approach for location analysis and evaluation of urban photovoltaic charging station: A case study in Beijing," Energy Conversion and Management, Vol.205(2020), p.112340.

17. Ö. Kaya, A. Tortum \& K.D. Alemdar et al., "Site selection for EVCS in Istanbul by GIS and multicriteria decision-making," Transportation Research Part D: Transport and Environment, Vol.80(2020), p.102271.

18. L.S Thomas, "How to make a decision : The Analytic Hierarchy Process," European Journal of Operational Research, Vol 48(1990), p.9-26 